\title{
HPLC MONITORING OF PCDD/Fs LEVELS IN FISH SPECIES COLLECTED FROM THE EGYPTIAN MARKET
}

\author{
G.O. El-Sayed , A. Marsafy ${ }^{2}$, Y. Nabil and R. Husien $^{2}$ \\ ${ }^{1}$ Analytical Chemistry Department, Faculty of Science, Benha University, Egypt. \\ ${ }^{2}$ Central Laboratory of Residue Analysis of Pesticide and Heavy Metals in food, Agriculture Research Center, \\ Cairo, Egypt.
}

\begin{abstract}
Chemical pollutants released from various industries into water systems make fish a sources of various environmental toxicants to humans and classified fish consumption as one of the primary pathways of exposure to polychlorinated dibenzo-p-dioxins, dibenzofurans ( $\mathrm{PCDD} / \mathrm{Fs})$ and dioxin like polychlorinated biphenyls (dlPCBs). The current study was conducted on 31 randomly collected individual fish samples marketed in different governorates in Egypt, during 2011-2012 to evaluate tissue levels of the 17 laterally substituted polychlorinated dibenzo-p-dioxins, dibenzofurans (PCDD/Fs) and 12 dioxin like polychlorinated biphenyls (dl-PCBs). The mean total TEQ value found in fish was 0.625 and concentrations ranged from 0.063 to $3.981 \mathrm{pg}$ WHO-TEQ/g product, such levels were lower than the EU regulations limits of 2006 (8pg WHO-TEQ/g product). The highest concentrations when the results were expressed in toxic equivalents corresponded to 2,3.4,7,8-PeCDF, PeCDD and TCDD; and PCB-126 being the most frequentof dl-PCBs. The average PCDD/Fs and dl-PCBs intakes based on adaily fish consumption of $14.5 \mathrm{~g}$ was estimated at $0.15 \mathrm{pg}$ WHO-TEQ $\mathrm{kg}^{-1} \mathrm{~b} . \mathrm{w} . \mathrm{d}^{-1}$ for adults, which was lower than range of TDI recommended by the WHO (1-4 pg WHO-TEQ kg ${ }^{-1}$ b.w. $\left.\mathrm{d}^{-1}\right)$, and much lower than the TWI and PTMI adopted by SCF and JECFA, respectively.
\end{abstract}

Keywords: dioxin derivatives, determination, fish.

\section{Introduction}

Polychlorinated dibenzo-p-dioxins (PCDDs), polychlorinated dibenzofurans (PCDFs), and polychlorinated biphenyls (PCBs) are three classes of chemically and structurally related polyhalogenated aromatic hydrocarbons and, Each of these groups consist of 75, 135 and 209 theoretical individual congeners,respectively, based on the number and position of chlorine atomsin the chemical structure(Gilpin et al., 2003). They usually occur as a mixture of congeners, and their ubiquity, high chemical and metabolic persistence, and potent toxicity of some of the congeners make them a well recognized class of persistent organic pollutants (POPs) which are included in the Stockholm Convention (UNEP, 2001).

Food consumption is the main route for human exposure toPCDD/Fs and dioxin-like PCBs, following bioaccumulation of thesecompounds in the aquatic and terrestrial food chains. Fish and seafood,meat and meat products, and dairy products have been reportedas some of the major sources of exposure in adults and children (Bordajandi et al., 2004). The strategy to reduce dioxin intakes has led to numerous surveystudies on the concentration of dioxins in particular food itemssuch as fish (Gomara et al., 2005). Several studies have performed assessments of the intake of dioxins from the diet (Kroeset al., 2002), using different approaches such as market basket monitoring programmes (Wang et al., 2009), (Bilau et al., 2008), or total diet studies (Windal et al., 2010).

The present study is intended to assess the levels of the biologically active congeners in fish, and to evaluate whether the present levels of dioxins and dioxin-like PCBs exceed the maximum permitted levels according to EU Council regulation, to establish the contribution of dioxins, furans and coplanar PCBs to the toxic equivalent quantities (WHO-TEQ) in foodstuffs, and asses the dietary exposure of adults.

\section{Materials and Methods}

\section{Sampling}

A total of 31 fish samples were randomly collected from local markets in different governorates in Egypt during 2011-2012. Samples were analyzed in the central laboratory of residue 
analysis and heavy metals in food, and the results grouped to evaluate average levels and ranges of PCDD/Fs and dioxin-like PCBs.

\section{Chemicals and Reagents:}

All solvents (Toluene, n-Hexane, Methanol,Methylene Chloride and Nonane) used were of pesticide grade and purity not less than $99 \%$, Silica gel and basic Alumina were from Aldrich (Brockmann I, standard grade, Milwaukee, USA), anhydrous sodium sulphate and conc. $\mathrm{H}_{2} \mathrm{SO} 4(96 \%)$ were from Riedel-deHaen, carbopack C- 80/100 (Supelco) and celite 545- (BDH or Aldrich). Calibration standard solutions, labeled standard and injection solutions specified in EPA Method-1613B were obtained from Cambridge Isotopes Laboratories (Andover, USA).

\section{Extraction}

Extraction of fat from fish samples $(25 \pm 0.1 \mathrm{~g})$ was carried out by Soxhlet or Accelerated Solvent Extractor (ASE) using a solvent mixture of n-Hexane: Dichloromethane (1:1). The lipid was extracted from the samples using either soxhlet or ASE then transfered to cleanup steps.

Accelerated Solvent Extractor - Dionex 350; condition of ASE: Oven temp.: $125 \mathrm{C}^{\circ}$, Static cycle time: 5 minute, Cycles: 4, Rinse volume: $80 \%$, Purge time: 70 Sec, Cell pressure: 1500 psi (nitrogen gas) and Total extraction time: $30 \mathrm{~min}$ per sample.

Clean-up
Clean-up steps were conducted according to EPA Method (USEPA 1994), using acidified silica gel, anthropogenic, multilayer silica gel, alumina and active carbon column. Finally PCDDs/Fs and dl-PCBs were determinated by using HRGC/HRMS.

\section{HRGC/HRMS Instrument}

Analyses were conducted using HP 6890 plus gas chromatograph coupled with Micromass /Autospec Ultima mass spectrometer operating in EI mode at $35 \mathrm{eV}$ and with a resolution of $10.000(5 \%$ valley). Sample injection was performed in the splitless mode on DB5 MS column $(60 \mathrm{~m}, 0.25 \mathrm{~mm}$ id, $0.1 \mu \mathrm{m}$ film thickness). The oven program was started from $90^{\circ} \mathrm{C}$ then took $15 \mathrm{~min}$. to reach $220^{\circ} \mathrm{C}$ then held for $15 \mathrm{~min}$, then from $220-290{ }^{\circ} \mathrm{C}$ in $8 \mathrm{~min}$ then held for $17 \mathrm{~min}$. Helium (Ultra high purity) at a flow rate $0.8 \mathrm{~mL} / \mathrm{min}$. was used as a carrier gas. Injector temperature was $225 \mathrm{C} ; 2 \mu \mathrm{L}$ of the sample injected using splitless mode.

\section{Quality Assurance/Quality control (QA/QC):}

The QCAP lab. Followed the quality assurance system as shown in Table 1. Method blank, ongoing precision and recovery (OPR), certified reference material (CRM) and quality control samples were included with each batch of 20 samples to confirm the laboratory performance and method validation. Method of analysis of PCDDs/Fs and dioxin-like PCBs in fish were accredited by the Finnish Accreditation Service body (FINAS) according to the requirements of the International Standard ISO/IEC 17025.

Table 1. LOD and average recoveries of PCDDs/Fs tested with fish samples analyzed.

\begin{tabular}{lcccc}
\hline Labeled PCDD/Fs & $\begin{array}{l}\text { OD } \\
\text { ng/ml) }\end{array}$ & $\begin{array}{l}\text { ixpected Conc. } \\
\text { ng/ml) }\end{array}$ & Average Recovery $\%$ & Acceptance Av. Rec. Range \% \\
\hline 2,3,7,8-TCDD & 0.01 & 100 & 55.2 & $25-164$ \\
$1,2,3,7,8-P e C D D$ & 0.01 & 100 & 55.8 & $25-181$ \\
$1,2,3,4,7,8-H x C D D$ & 0.05 & 100 & 77.1 & $32-141$ \\
$1,2,3,6,7,8-H x C D D$ & 0.05 & 100 & 81.7 & $28-130$ \\
$1,2,3,4,6,7,8-H p C D D$ & 0.05 & 100 & 65.1 & $23-140$ \\
$1,2,3,4,6,7,8,9-O C D D$ & 0.1 & 200 & 52.8 & $17-157$ \\
$2,3,7,8-$ TCDF & 0.01 & 100 & 69.1 & $24-169$ \\
$1,2,3,7,8-P e C D F$ & 0.01 & 100 & 61.7 & $21-178$ \\
$2,3,4,7,8-P e C D F$ & 0.01 & 100 & 55.5 & $26-152$ \\
$1,2,3,4,7,8-H x C D F$ & 0.05 & 100 & 81.7 & $26-123$ \\
$1,2,3,6,7,8-H x C D F$ & 0.05 & 100 & 85.4 & $28-143$ \\
$2,3,4,6,7,8-H x C D F$ & 0.05 & 100 & 79.5 & $26-138$ \\
$1,2,3,4,6,7,8-H p C D F$ & 0.05 & 100 & 89.6 & $17-157$ \\
$1,2,3,4,7,8,9-H p C D F$ & 0.05 & 100 & 74.8 & \\
$1,2,3,4,6,7,8,9-O C D F$ & 0.1 & 200 & 57.6 & \\
\hline
\end{tabular}

\section{Quantitative determination}

Determinations of PCDD/Fs were performed by an isotope dilution method using relative response factors previously obtained from five standard solutions. The TEQ concentrations were calculated guided by the World Health Organization-toxic equivalent factor (WHO-TEFs, 1998), The tetra through octa $\mathrm{PCDD} / \mathrm{F}$ results were identified, quantified and presented in pg WHO-TEQ/g fat 
weight multiplied by the associated WHO-TEF (Van den Berget et al., 1998). It assumed that non-detected isomer concentrations were equal to the limits of determination. As recommended by the European Regulation (EC 2006), detection and quantification limits, as well as recoveries, for all PCDD/Fs congeners were in good agreement with requirements laying down the sampling methods and methods of analysis for the official control of PCDD/Fs. For each run, samples were prepared including a method blank and quality control samples. All steps of analysis were conducted according to the U.S adverse consequences of the observed effects USEPA 1994.

\section{Results and Discussion}

\subsection{Toxic equivalency in fish}

Concentrations of congeners for fish samples are expressed in pg WHO-TEQ/g product, in accordance with the European Council Regulation. The mean total TEQ value found in fish was 0.625 with a concentration range of 0.063 to $3.981 \mathrm{pg}$ WHO$\mathrm{TEQ} / \mathrm{g}$ product; this level is lower than the EU limits $8 \mathrm{pg}$ WHO-TEQ/g product. The mean concentration of PCDD/F was $0.592 \mathrm{pg}$ WHO-TEQ/g products, this level was lower than the EU limits 4pg WHO-TEQ/g product with concentration range of 0.06 to $3.618 \mathrm{pg}$ WHO-TEQ/g product. For dl-PCBs the mean concentration was $0.033 \mathrm{pg}$ WHO-TEQ/g product with concentration ranged of 0.003 to $0.065 \mathrm{pg}$ WHO-TEQ/g product see table 2 .

Table 2. Minimum, maximum and mean range of PCDD/Fs and Dl-PCBs for fish samples in pg WHO-TEQ/g product.

\begin{tabular}{|c|c|c|c|}
\hline Congeners & Min & $\operatorname{Max}$ & Mean \\
\hline $2,3,7,8-\mathrm{TCDD}$ & 0.006 & 0.261 & 0.058 \\
\hline 1,2,3,7,8-PeCDD & 0.010 & 0.658 & 0.105 \\
\hline 1,2,3,4,7,8-HxCDD & 0.001 & 0.011 & 0.003 \\
\hline $1,2,3,6,7,8-\mathrm{HxCDD}$ & 0.001 & 0.041 & 0.008 \\
\hline $1,2,3,7,8,9-\mathrm{HxCDD}$ & 0.001 & 0.008 & 0.003 \\
\hline $1,2,3,4,6,7,8-\mathrm{HpCDD}$ & 0.0002 & 0.007 & 0.002 \\
\hline $1,2,3,4,6,7,8,9-\mathrm{OCDD}$ & 0.000004 & 0.001 & 0.0003 \\
\hline $2,3,7,8-\mathrm{TCDF}$ & 0.003 & 0.079 & 0.037 \\
\hline 1,2,3,7,8-PeCDF & 0.001 & 0.018 & 0.006 \\
\hline $2,3,4,7,8-\mathrm{PeCDF}$ & 0.009 & 1.991 & 0.255 \\
\hline $1,2,3,4,7,8-\mathrm{HxCDF}$ & 0.002 & 0.286 & 0.050 \\
\hline $1,2,3,6,7,8-\mathrm{HxCDF}$ & 0.001 & 0.150 & 0.023 \\
\hline $2,3,4,6,7,8-\mathrm{HxCDF}$ & 0.001 & 0.069 & 0.015 \\
\hline $1,2,3,7,8,9-\mathrm{HxCDF}$ & 0.0005 & 0.018 & 0.005 \\
\hline $1,2,3,4,6,7,8-\mathrm{HpCDF}$ & 0.0002 & 0.091 & 0.019 \\
\hline $1,2,3,4,7,8,9-\mathrm{HpCDF}$ & 0.00008 & 0.003 & 0.001 \\
\hline $1,2,3,4,6,7,8,9-\mathrm{OCDF}$ & 0.000002 & 0.001 & 0.0001 \\
\hline PCB 77 & 0.000003 & 0.001 & 0.0002 \\
\hline PCB 81 & 0.000002 & 0.00004 & 0.00001 \\
\hline PCB 126 & 0.003 & 0.052 & 0.026 \\
\hline PCB 169 & 0.0002 & 0.001 & 0.0004 \\
\hline PCB 105 & 0.00001 & 0.002 & 0.001 \\
\hline PCB 114 & 0.00002 & 0.001 & 0.0003 \\
\hline PCB 118 & 0.00002 & 0.005 & 0.003 \\
\hline PCB 123 & 0.000003 & 0.001 & 0.0002 \\
\hline PCB 156 & 0.0002 & 0.003 & 0.002 \\
\hline PCB 157 & 0.0001 & 0.001 & 0.0003 \\
\hline PCB 167 & 0.000002 & 0.00003 & 0.00002 \\
\hline PCB 189 & 0.00001 & 0.00005 & 0.00003 \\
\hline Total PCDD/F & 0.060 & 3.618 & 0.592 \\
\hline Total PCBs & 0.003 & 0.065 & 0.033 \\
\hline Total TEQ & 0.063 & 3.981 & 0.625 \\
\hline
\end{tabular}

This trend was in agreement with that derived from studies by Scott et al., (2009) who reported that the total TEQ concentration ranged from 0.1 to $4.3 \mathrm{pg}$ WHO-TEQ/g product for wild-caught fish. Also, the obtained results were in agreement with that reported by Wei et al., (2011) who reported that the total PCDD/Fs TEQ levels in fish meat was 0.27 to $3.8 \mathrm{pg}$ WHO-TEQ/g product and dl-PCBs ranged from 0.065 to $5.25 \mathrm{pg}$ WHO-TEQ/g product. 
The percentage of each $\mathrm{PCDD} / \mathrm{F}$ congener in fish samples, as concentrations (pg/g product) and toxic equivalents (pg WHO-TEQ/g product) are shown in Figure 1.The profile of concentrations was dominated by OCDD, 1,2,3,4,6,7,8 HpCDF and OCDF congeners whose combined concentrations account for $67.50 \%$ of all PCDD/Fs. When the percentage is expressed in toxic equivalents, the most abundant congeners were 2,3.4,7,8-PeCDF, PeCDDand the TCDD, that together account for the $68.14 \%$ of total dioxins. This could be explained because TCDD, PeCDD and 2,3.4,7,8-PeCDF congeners present the highest WHO-TEF for TCDD , PeCDD $(\mathrm{TEF}=1)$ and for PCDFs $(\mathrm{TEF}=0.5)$.

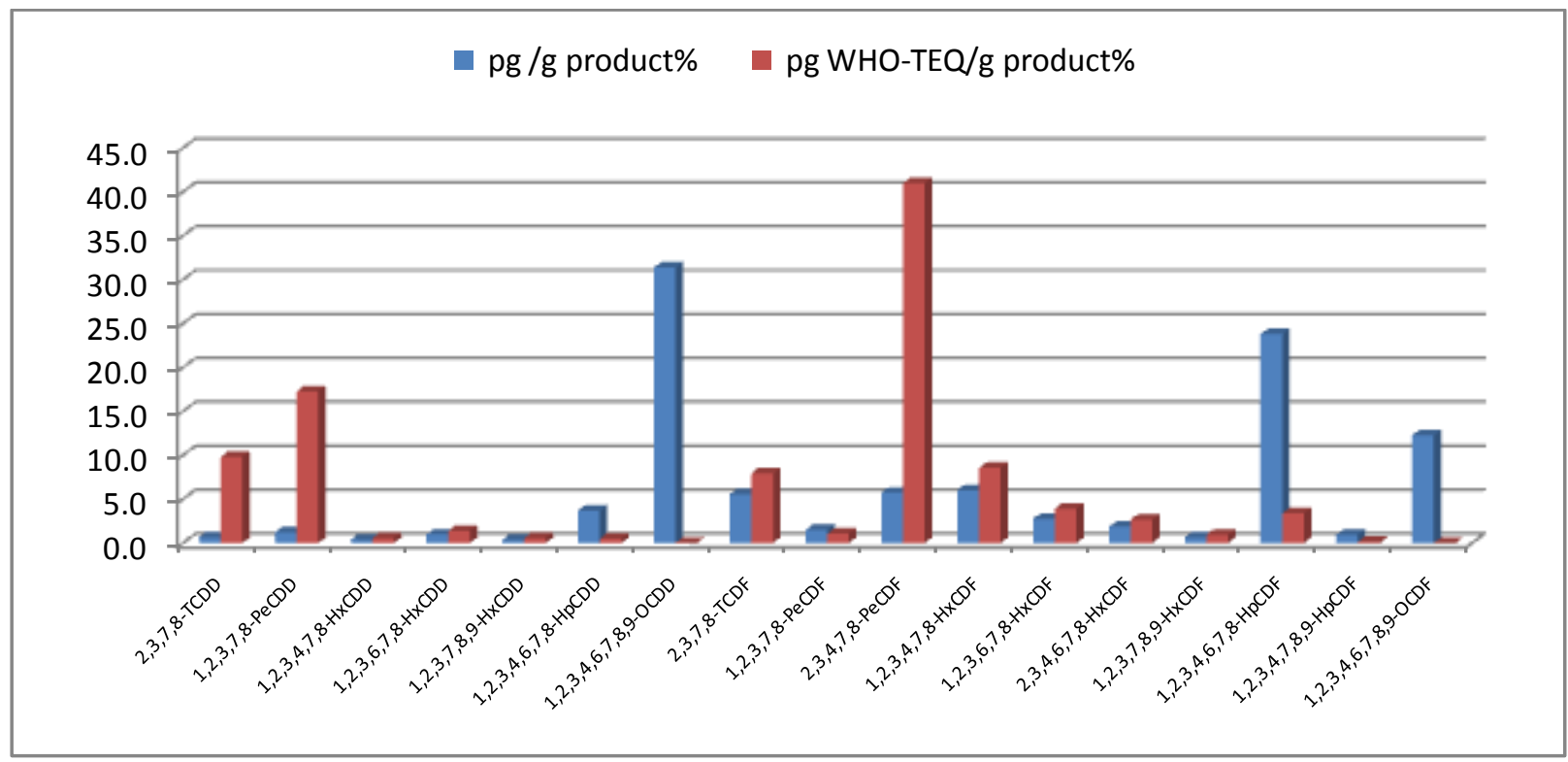

Figure 1: The percentage of individual PCDD/Fs congeners in fish samples as toxic equivalents.

For dl-PCBs, the mono-ortho PCB-118 represents $55.48 \%$ of the total concentration, however, in terms of percentage from toxic equivalents, it is the most toxic PCB-126 (WHO$\mathrm{TEF}=0.1$ ) that accounts for the highest contribution (79.6\%), as shown in figure 2 .

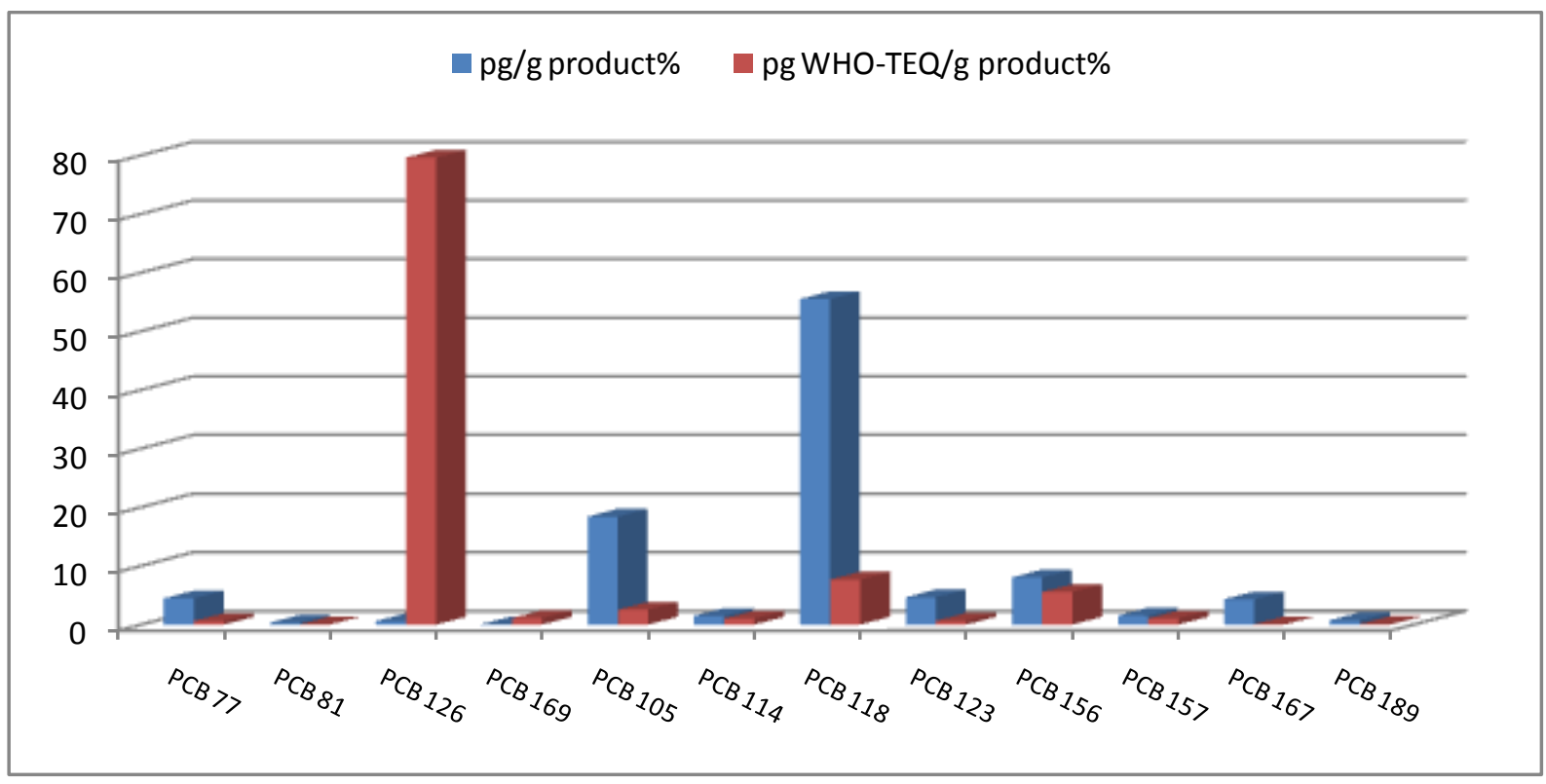

Figure 2. The percentage of individual DL-PCBs congeners in fish samples as toxic equivalents.

For PCDD/Fs samples of the highest content were found in $\mathrm{Al}$ Qalyobia governorate; the mean result was $2.575 \mathrm{pg}$ WHO-TEQ/g product. The lowest samples were found in Giga governorate, the mean result was $0.094 \mathrm{pg}$ WHO-TEQ/g products, as shown in Figure 3. 


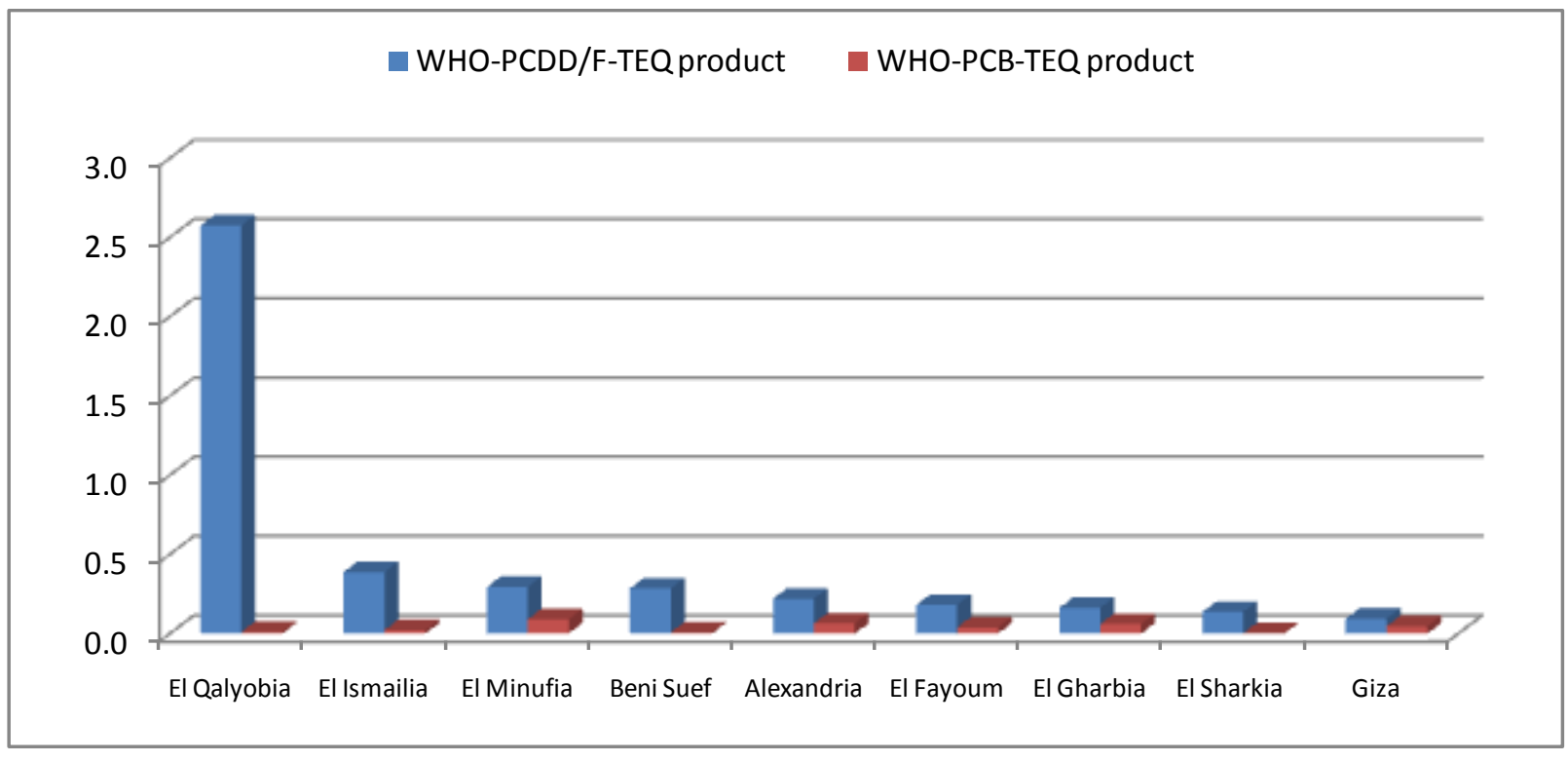

Figure 3. Average concentration of profile PCDDs/Fs of fish (pg WHO-TEQ/g) from different Egyptian governorates in fish samples.

\subsection{Estimate of dietary exposure to PCDD/Fs and dl-PCBs}

This monitoring study has been designed mainly to assess contamination levels of $\mathrm{PCDD} / \mathrm{Fs}$ and $\mathrm{dl}-$ PCBs in fish and to evaluate if the levels are in accordance with those established by the EU legislation. The results could also be used to perform an approximate estimation of the average daily intake of the population of Egypt. In the current survey, food consumption data were obtained from GEMS 2006. The average $\mathrm{PCDD} / \mathrm{Fs}$ and $\mathrm{dl}-\mathrm{PCB}$ intakes based on adaily fish consumption of $14.5 \mathrm{~g}$ was estimated at $0.15 \mathrm{pg}$ WHO-TEQ $\mathrm{kg}^{-1}$ b.w. $\mathrm{d}^{-1}$ for adults, which was lower than the range of TDI recommended by the WHO (1-4 pg WHO-TEQ $\mathrm{kg}^{-}$ ${ }^{1}$ b.w. $\mathrm{d}^{-1}$ ), and much lower than the TWI and PTMI adopted by SCF and JECFA, respectively

The percentage ofPCDD/Fs daily intake and dLPCBs daily intake are shown in Figure 4.

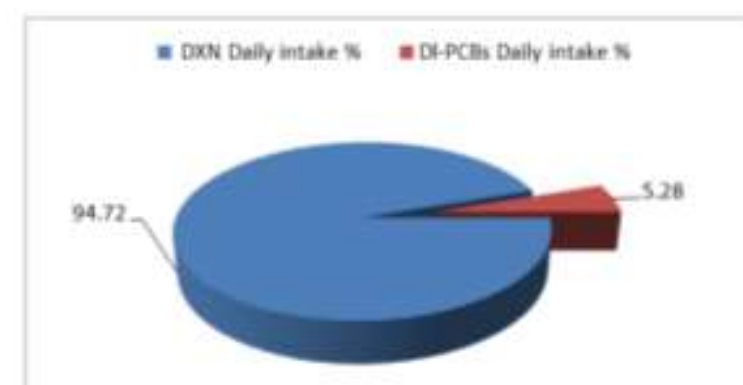

Figure 4. Distribution of dioxin and dl-PCBs daily intake from fish markets.

\section{Conclusion}

In all analyzed samples, the most found and the highly detected PCDD/Fsand dl-PCBs congeners were OCDDthen OCDF; and PCBs 118, 105 and 156 , respectively.This means that there are ongoing sources for these pollutants. Therefore there must be a strict supervision on all sources that may cause contamination of Egyptian food. It is recommended to continue the monitoring programs in the Egyptian markets to trace, investigate and estimate these pollutants in food to help decision makers to take steps that protect the health of Egyptian Citizens.

\section{Acknowledgements}

For Central Lab of Residue Analysis of Pesticides and Heavy Metal in Food-(QCAP), Agricultural Research Center, Egypt.

\section{References}

Bilau, M., Matthys, C., Baeyens, W., Bruckers, L., Backer, G.D., Hond, E.D., Keune, H.,Koppen, G., Nelen, V., Schoeters, G., Van Larebeke, N., Willems, J.L., and De Henauw,S., 2008. Dietary exposure to dioxin-like compounds in three age groups: resultsfrom the Flemish environment and health study. Chemosphere, 70 : 584-592.

Bordajandi, L.R., Gomez, G., Abad, E., Rivera, J., Fernandez-Baston, M.D.M., Blasco, J.,Gonzalez, M.J., 2004. Survey of persistent organochlorine contaminants (PCBs,PCDD/Fs, and $\mathrm{PAHs})$, heavy metals $(\mathrm{Cu}, \mathrm{Cd}, \mathrm{Zn}, \mathrm{Pb}$, and $\mathrm{Hg}$ ), and arsenic in foodsamples from Huelva 
(Spain): levels and health implications. J. Agric. FoodChem., 52: 992-1001.

EC 2006. Commission Regulation No. 199/2006 of 3 February amending Regulation No. 466/2001 setting maximum levels for certain contaminants in foodstuffs as regard to dioxins and dioxin-like PCBs. Off J Eu Union, L 2006; 32/34.

USEPA 1994. Environmental Protection Agency, U.S.A, Method 1613, "Tetra through octachlorinated dioxins and furans by isotope dilution HRGC/HRMS".

Gilpin, R.K., Wagel, D.J., and Solch, J.G., 2003. Production, distribution and fate of

polychlorinateddibenzo $\mathrm{p}$ dioxins, dibenzofurans, and related organohalogensin the

environment. In: Schecter, A., Gasiewicz, T.A. (Eds.), Dioxins and Health.Wiley-Interscience Hoboken, NJ, New Jersey, 952.

Gomara, B., Bordajandi, L.R., Fernandez, M.A., Herrero, L., Abad, E., Abalos, M.,

Rivera,J., and Gonzalez, M.J., 2005. Levels and trends of polychlorinated dibenzopdioxins/furans (PCDD/Fs) and dioxin-like polychlorinated biphenyls (PCBs) in Spanishcommercial fish and shellfish products,J. Agric. Food Chem. 53:8406-8413.

Kroes, R., Muller, D., Lambe, J., Lowik, M.R.H., van Klaveren, J., Kleiner, J., Massey,

R.,Mayer, S., Urieta, I., Verger, P., and Visconti, A., 2002. Assessment of intake from the diet. Food Chem. Toxicol., 40: 327-385.

Scott, L.L.F.; Staskal, D.F.; Williams, E.S.; Luksemburg, W.J.; Urban, J.D.; Nguyen,

L.M.; Haws, L.C.; Birnbaum, L.S.; Paustenbach, D.J.; and Harris, M.A., 2009. Levels of polychlorinated dibenzofurans, and biphenyls in southern Mississippi catfish and estimation of potential health risks.Chemosphere, 74: 1002-1010.

Wang, I., Wu, Y., Lin, L., and Chang-Chien, G., 2009. Human dietary exposure to

polychlorinateddibenzo-p-dioxins and polychlorinated dibenzofurans inTaiwan. J. Hazard. Mater. 164: 621-626.

Wei, X. ; Leung, K.S. ; Wong, M.H. ; Giesy, J. ; Cai, Z.W. ; and Wong, C. K.C., 2011.

Assessment of risk of PCDD/Fs and dioxin-like PCBs in marine and freshwater fish in PearlRiver Delta, China. Marine Pollution Bulletin, 63 (5-12): 166-171.

Windal, I., Vandevijvere, S., Maleki, M., Goscinny, S., Vinkx, C., Focant, J.F., Eppe, G.,Hanot, V., and Van Loco, J., 2010. Dietary intake of PCDD/Fs and dioxin-like PCBs of the Belgian population. Chemosphere 79: 334-340.

WHO1998. WHO experts re-evaluate health risks from dioxins. Press Release World Health Organization WHO/45, 3 June 1998.

Van den Berg, M., L.S., Birnbaum, A.T.C., Bosveld, B., Brunstro m, P., Cook, M., Feeley,J.P., Giesy, de A., Hanberg, R., Hasegawa, S.W., Kennedy, T., kubiak, J.C., Larsen, F.X.R., Van Leuwen, A.K.D., Liem, C., Nolt, R.E., Peterson, I., Poellinger, S.h., Safe, D.,Schrenk, D., Rillitt, m., Tysklind, M., Younes, F., Waern, T., and Zachrewski., 1998. Toxic equivqlency factors (TEFs) for PCB`s, PCDDs, PCDFs for humans and wildlife. Environ. Health Perspect, 106(12): 775-792.

UNEP 2001. Stockholm Convention on Persistent Organic Pollutants. United Nations Environment Programme. 